\title{
Multiple Intelligences of the High Primary Stage Students
}

\author{
Dr. Emad M. Al-Salameh \\ Special Education Department, Al- Balqa' Applied University \\ PO box 15, Salt, Jordan
}

Tel: 962-777-238-617 E-mail: imad_alsalameh@yahoo.com

Received: January 8, 2012

Accepted: January 29, $2012 \quad$ Published: March 1, 2012

doi:10.5539/ijps.v4n1p196

URL: http://dx.doi.org/10.5539/ijps.v4n1p196

\begin{abstract}
This study aims to investigate the multiple intelligences fields among high primary stage students and its relation with academic classification and gender. To fulfill this, (400) students were selected by stratified random way from Salt city government schools. Results can be summarized as follows: The excellent students have high levels of all multiple intelligences fields, while normal students have average levels of all multiple intelligences fields. There were statistically significant differences among high primary stage students in all multiple intelligences fields related to the variable of academic classification (excellent students, normal students) in favor for excellent students. There were no statistically significant differences in overwhelming majority of multiple intelligences fields among high primary stage students due to gender variable.
\end{abstract}

Keywords: Multiple intelligences, High primary stage, Excellent students

\section{Introduction}

Individuals differ in multiple brain activities, and in response to situations. This diversity led to variation of conceptual basis for the intelligence theories. The most important of these theories is the multiple intelligences theory, which was developed by Gardner in 1983. Gardner (1997) noted that individuals who have extraordinary abilities may get only middle grades on IQ tests, the reliability of IQ tests are not fair to reveal the individual differences. Therefore, he tended to identify the integrated components of intelligence, also Gardner (1998) noted that the intelligence is a Bio-psychological latent energy which is active in cultural context in order to solve problems creatively.

The theory of multiple intelligences was developed first as an account of human cognition that could be subjected to empirical tests. When Gardner wrote Frames of Mind, he believed that his work would be of interest chiefly to persons trained in his discipline of developmental psychology. Yet Frames of Mind did not arouse much interest within the discipline of developmental psychology; most developmental psychologists ignored it. The reception among educators, however, was quite different. The theory of multiple intelligences seems to harbor a number of educational implications that are worthy of consideration. Armstrong (1994) synthesized these ideas into four key points that educators find attractive about the theory:

First: Each person possesses all nine intelligences. In each person the eight intelligences function together in unique ways. Some people have high levels of functioning in all or most of the eight intelligences; a few people lack most of the rudimentary aspects of intelligence. Most people are somewhere in the middle, with a few intelligences highly developed, most modestly developed, and one or two underdeveloped.

Second: Intelligences can be developed. Gardner suggests that everyone has the capacity to develop all nine intelligences to a reasonably high level of performance with appropriate encouragement, enrichment, and instruction.

Third: Intelligences work together in complex ways. No intelligence really exists by itself in life, Intelligences are always interacting with each other.

Fourth: There are many different ways to be intelligent. There is no standard set of attributes that one must have in order to be considered intelligent.

Isik and Tarim (2009) indicated that intelligence is not fixed, but it can be increased through development, 
training and learning. Gardner's theory is an extension of Turnstone's theory which is known as primary mental abilities theory. Willis \& Johnson (2001) pointed that the Gardner's multiple intelligences theory caused a major transition in intelligence study, he found that the human mind is divided into moulds, each mould is responsible for mental process and specific patterns intelligence, These moulds can be refined through education and training, it's product of a unique interaction between genetics and cultural environment. Weinreich-Haste (1985) claims that many people are surprised at some of the intelligence categories that Gardner has chosen because they never think of these areas as being related to "intelligence." They think of the categories more as talents or aptitudes.

Gardner identified eight intelligences and has since added a ninth. The list is not meant to be final or exhaustive. The point is not the exact number of intelligences, but simply the plurality of the intellect. Each person has raw biological potential. We differ in the particular intelligence profiles with which we are born and the ways in which we develop them.

Linguistic intelligence: the ability to use words effectively both orally and in writing. This intelligence includes such skills as the abilities to remember information, to convince others to help you, and to talk about language itself.

Logical-mathematical intelligence: the ability to use numbers effectively and reason well. This includes such skills as understanding the basic properties of numbers and principles of cause and effect, as well as the ability to predict, using simple machines, the ability to abstract thinking, understanding relationships, classification and organization.

Visual Spatial intelligence: the ability to sense form, space, color, line, and shape. It includes the ability to graphically represent visual or spatial ideas, the ability to perceive visual- spatial world, understanding of shapes, re-create perceptions of visual stimuli in the absence of natural, sensitivity to nature and relationships between elements.

Bodily-kinesthetic intelligence: the ability to use the body to express ideas and feelings and to solving problems. This includes such physical skills as coordination, flexibility, speed, and balance.

Musical Intelligence: the ability to sense rhythm, pitch, and melody. This includes such skills as the ability to recognize simple songs and to vary speed, tempo, rhythm in simple melodies, and the ability to perceive and produce the different musical formats.

Interpersonal intelligence: ability to understand another person's moods, feelings, motivations, and intentions. This includes such skills as responding effectively to other people in some pragmatic way, such as getting students or colleagues to participate in a project, ability to discover and understand the psychological state of others, their motives, desires and feelings, to respond in an appropriate way, sensitive to facial expressions, voice tone and gestures.

Intrapersonal intelligence: the ability to understand yourself-your strengths, weaknesses, moods, desires, and intentions. This includes such skills as understanding how you are similar to or different from others, reminding yourself to do something, knowing about yourself as a language learner, and knowing how to handle your feelings, such as what to do and how to behave when you are angry or sad, ability to understand the awareness of internal feelings, values, beliefs and thinking, ability to use the information in planning and doing the right thing.

Naturalist intelligence: the ability to recognize and classify plants, minerals, and animals, including rocks and grass, and all variety of flora and fauna. It is also the ability to recognize cultural artifacts like cars or sneakers.

Existential intelligence: the ability to ask and try to answer the big questions which related to existence, and the deep meaning of life (Karen, 2002).

For the important role of multiple intelligences theory many studies were conducted concerning its relationship with many variables, such as the academic specialization, academic achievement, gender and other variables. Loori (2005) pointed that there were significant differences between males' and females' preferences of intelligences. Males preferred learning activities involving logical and mathematical intelligences, whereas females preferred learning activities involving intrapersonal intelligence. Furnham \& Akande (2004), pointed that there were differences in multiple intelligences between males and females in favor of females.

\section{Study Questions}

i. What are the levels of multiple intelligences fields among high primary stage students?

ii. Are there statistically significant differences in multiple intelligences fields among high primary stage students due to academic classification (excellent students, normal students)? 
iii. Are there statistically significant differences in multiple intelligences fields among high primary stage excellent students due to gender?

iv. Are there statistically significant differences in multiple intelligences fields among high primary stage normal students due to gender?

\section{Limitations}

Results would be limited by Validity and reliability coefficients for the scale which is used in the current study.

\section{Methods}

\subsection{Participants}

The population of the study consists of all students in high primary stage (the seventh, eighth, ninth, tenth grade) enrolled during the academic year 2011/2012 at Salt government schools in Jordan. The sample of the study consists of (400) students selected by stratified randomly from Salt government schools. Table 1 shows participants characteristics.

\section{Insert Table 1 Here}

\subsection{Instrument}

For the purposes of the current study, the researcher prepared a scale of multiple intelligences appropriate for high primary stage students, by reference to the literature about multiple intelligences, specially Gardner's multiple intelligences theory, and measurements of multiple intelligences, such as: a list of Gardner (Gardner, 2004), a list of McKenzie (McKenzie, 1999), a list of Armstrong (Armstrong, 1994), a list of evaluation of multiple intelligences in a learning program in California (California Distance Learning Program, 1996).

The scale consisted of (90) items measure the following nine fields of multiple intelligences: (Linguistic Intelligence, Logical Mathematical Intelligence, Visual Spatial Intelligence, Body-Kinesthetic Intelligence, Musical Intelligence, Interpersonal Intelligence, Intrapersonal Intelligence, Naturalist Intelligence, and Existential Intelligence). Every ten items measure one field from multiple intelligences fields. The amount of sub-scores ranged among (10-50) degrees. The researcher investigates the validity of the scale through Logical Validity, and Construct Validity. Table 2 shows Pearson's correlation coefficients of the items with the multiple intelligences fields, and total degree. The researcher investigates the reliability of the scale by the following methods: (Test- Retest reliability, Split- Half Reliability. and Internal Consistency Reliability) of the scale items, table 3 shows the reliability coefficients for the scale.

\section{Insert Table 2 Here \\ Insert Table 3 Here}

To explain the sub-scores, the means were divided into four levels as follows: mean less than (2.66) refers to the low level of multiple intelligences field, score among (2.66-3.33) refers to the average level of multiple intelligences field, and score more than (3.33) refers to the high level of multiple intelligences field.

\section{Results}

\subsection{Results Related to Question One}

What are the levels of multiple intelligences fields among high primary stage students? To answer this question, means and standard deviations were computed for grades obtained by participants on the multiple intelligences fields scale as shown by tables 4,5 . Table 4 shows that excellent students have high levels of all multiple intelligences fields. Also it shows the descending order of multiple intelligences fields for excellent students as follows: (Logical- Mathematical intelligence, Interpersonal intelligence, Bodily-Kinesthetic intelligence, Visual Spatial intelligence, Existential intelligence, Naturalist intelligence, Intrapersonal intelligence, Linguistic intelligence, and Musical intelligence). While Table 5, on the other hand, shows that normal students have average levels of all multiple intelligences fields. It also shows the descending order of multiple intelligences fields for normal students as follows: (Musical intelligence, Linguistic intelligence, Visual Spatial intelligence, Naturalist intelligence, Logical- Mathematical intelligence, Bodily-Kinesthetic intelligence, Intrapersonal intelligence, Existential intelligence, and Interpersonal intelligence).

Insert Table 4 Here

Insert Table 5 Here

\subsection{Results Related to Question Two}

Are there statistically significant differences in multiple intelligences fields among high primary stage students 
due to academic classification variable (excellent students, normal students)? To answer this question, means, standard deviations and T-Value were computed for grades obtained by participants on the multiple intelligences fields scale as shown by table 6 . Table 6 shows that there were statistically significant differences in all multiple intelligences fields related to the variable of academic classification (excellent students, normal students) in favor for excellent students.

Insert Table 6 Here

\subsection{Results Related to Question Three}

Are there statistically significant differences in multiple intelligences fields among high primary stage excellent students due to gender variable? To answer this question, means, standard deviations, and T-Value were computed for grades obtained by participants on the multiple intelligences fields scale as shown by table 7. Table 7 shows that there were statistically significant differences in Naturalist intelligence field among excellent students related to the variable of gender, in favor for male. And it shows there were no statistically significant differences in other multiple intelligences fields among excellent students due to gender variable.

\section{Insert Table 7 Here}

\subsection{Results Related to Question Four}

Are there statistically significant differences in multiple intelligences fields among high primary stage normal students due to gender variable? To answer this question, means, standard deviations. And T-Value was computed for grades obtained by participants on the multiple intelligences fields scale as shown by table 8 . Table 8 shows that there were statistically significant differences in Interpersonal intelligence field among normal students related to the variable of gender, in favor for male. And shows there were no statistically significant differences in other multiple intelligences fields among normal students due to gender variable.

\section{Insert Table 8 Here}

\section{Discussion}

The results of the current study show that high primary stage excellent students have high levels of all multiple intelligences fields, while high primary stage normal students have average levels of all multiple intelligences fields. It also shows that there were statistically significant differences in all multiple intelligences fields related to the variable of academic classification (excellent students, normal students) in favor for excellent students. This result may be due to the nature of the cognitive, behavioral, mental, physical, emotional and social characteristics of excellent students such as: "The powerful memory", "the power of focus", "love of reading", "a curiosity, independence", "clarity of thinking", "extensive imagination", "power of observation", "abstract thinking", "moral development", "the diversity of interests and hobbies", "ability to express ideas and feelings", "flexibility in thinking and behavior", "fluency", "sensitivity to problems", "reflective thinking", "physical health", "social adjustment", "psychological adjustment", "and motor skills". Studies indicated that excellent students have high levels of these characteristics (Cathie, 2004). This is in turn makes them have high levels of all multiple intelligences fields, and make them excel to normal students.

On the other hand, the results indicate that there were no statistically significant differences in overwhelming majority of multiple intelligences fields among high primary stage (excellent $\&$ normal) students due to gender variable. This result is due to the cultural mobile and openness, equal of opportunities, media openness, awareness, high level of education and great attention to females in the Jordanian society. This is in turn reduced the differences between males and females in different areas, in general, and in multiple intelligences fields specifically.

\section{Conclusion \& Applications}

The conclusion of the current study is that high primary stage excellent students have high levels of all multiple intelligences fields, while normal students have average levels of all multiple intelligences fields. And it shows that there were statistically significant differences in all multiple intelligences fields among high primary stage students related to the variable of academic classification (excellent students, normal students) in favor for excellent students. Also, Results indicated that there were no statistically significant differences in overwhelming majority of multiple intelligences fields among high primary stage (excellent $\&$ normal) students due to gender variable. In the light of the results that are concluded by this study, it is recommended to pay greater attention to developing multiple intelligences fields among high primary stage normal students. Also, there should be a great focus on the following multiple intelligences fields: (Naturalist intelligence, Logical-mathematical intelligence, Bodily-kinesthetic intelligence, Intrapersonal intelligence, Existential intelligence, and Interpersonal 
intelligence), Through planning for teaching strategies, and academic guidance programs.

\section{References}

Armstrong, T. (1994). Multiple Intelligence in the Classroom. Alexandria, VA: ASCD.

California Distance Learning Program. (1996). [Online] Available: http://www.cdlp.rssd.k12.ca.us/ fovims/multip.htm

Cathie, H. (2004). Giftedness in Early Childhood: The Search for Complexity and Connection. Roper Review, 26 (1), 78-85.

Furnham, A., \& Akande, A. (2004). African parents' estimates of their own and their children's multiple intelligences. Current Psychology, 22, (4), 281-294. http://dx.doi.org/10.1007/s12144-004-1034-x

Gardner, H. (2004). Audiences for the Theory of Multiple Intelligences. Teacher College Record, 106 (1), $212-$ 220. http://dx.doi.org/10.1111/j.1467-9620.2004.00329.x

Gardner, H. (1983). Frames of Mind: The Theory of Multiple Intelligences. New York: Basic Books.

Gardner, H. (1993). Multiple intelligences: The theory and practice. New York: Basic Books.

Gardner, H. (1997). Extraordinary Minds: Portraits of Exceptional Individuals and an Examination of our Extraordinariness. New York: Basic Books.

Isik, D., \& Tarim, K. (2009). The effects of the cooperative learning method supported by multiple intelligence theory on Turkish elementary students' mathematics achievement. Asia Pacific Education Review, 10 (4), 465-474. http://dx.doi.org/10.1007/s12564-009-9049-5

John, A., \& Lori, J. (2005). The Analysis of the Emotional Intelligence Skills and Potential Problem Areas of Elementary Educators. Journal article Education, 125.

Karen, R. (2002). Empowering Students through Multiple Intelligences. Reclaiming Children and Youth, 10 (4), 233-35.

Loori, A. (2005). Multiple Intelligences: A Comparative Study between the Preferences of Males and Females. Social Behavior and Personality: an international journal, 33 (1), 77-88.

McKenzie, W. (1999). Multiple Intelligences Inventory. [Online] Available: http://Surfaquarium.com/MI/inventory. htm.

Weinreich-Haste, H. (1985). The varieties of intelligence: An interview with Howard Gardner. New Ideas in Psychology, 3 (4), 47-65. http://dx.doi.org/10.1016/0732-118X(85)90050-9

Willis, J., \& Johnson, A. (2001). Multiply with MI: Using Multiple Intelligences To Master Multiplication. Teaching Children Mathematics, 7 (4), 260-69. 
Table 1. Participants characteristics

\begin{tabular}{|c|c|c|c|}
\hline \multirow{2}{*}{ Academic classification } & \multicolumn{2}{|c|}{ Gender } & \multirow{2}{*}{ Total } \\
\hline \multirow{2}{*}{ Excellent students } & Male & Female & 200 \\
\cline { 2 - 4 } & 100 & 100 & 200 \\
\hline Normal students & 100 & 100 & 400 \\
\hline Total & 200 & 200 & \multirow{2}{*}{} \\
\hline
\end{tabular}

Table 2. Pearson's correlation coefficients of the items with the multiple intelligences fields scale, and total degree

\begin{tabular}{|c|c|c|c|c|c|c|c|c|}
\hline Item & $\begin{array}{l}\text { Correlation } \\
\text { With field }\end{array}$ & $\begin{array}{c}\text { Correlation } \\
\text { With total } \\
\text { degree }\end{array}$ & Item & $\begin{array}{l}\text { Correlation } \\
\text { With field }\end{array}$ & $\begin{array}{c}\text { Correlation } \\
\text { With total } \\
\text { degree }\end{array}$ & Item & $\begin{array}{l}\text { Correlation } \\
\text { With field }\end{array}$ & $\begin{array}{c}\text { Correlation } \\
\text { With total } \\
\text { degree }\end{array}$ \\
\hline 1 & $0.656(* *)$ & $0.653(* *)$ & 31 & $0.591(* *)$ & $0.520(* *)$ & 61 & $0.485(* *)$ & $0.567(* *)$ \\
\hline 2 & $0.520(* *)$ & $0.429(* *)$ & 32 & $0.619(* *)$ & $0.467(* *)$ & 62 & $0.394(* *)$ & $0.543(* *)$ \\
\hline 3 & $0.472(* *)$ & $0.301(* *)$ & 33 & $0.599(* *)$ & $0.454(* *)$ & 63 & $0.500(* *)$ & $0.459(* *)$ \\
\hline 4 & $0.610(* *)$ & $0.575(* *)$ & 34 & $0.471(* *)$ & $0.345(* *)$ & 64 & $0.319(* *)$ & $0.470(* *)$ \\
\hline 5 & $0.590(* *)$ & $0.471(* *)$ & 35 & $0.455\left(^{* *}\right)$ & $0.313(* *)$ & 65 & $0.480(* *)$ & $0.620(* *)$ \\
\hline 6 & $0.485(* *)$ & $0.435(* *)$ & 36 & $0.715(* *)$ & $0.545(* *)$ & 66 & $0.493(* *)$ & $0.546(* *)$ \\
\hline 4 & $0.561(* *)$ & $0.453(* *)$ & 37 & $0.553(* *)$ & $0.418(* *)$ & 67 & $0.312(* *)$ & $0.427(* *)$ \\
\hline 8 & $0.476(* *)$ & $0.274(* *)$ & 38 & $0.604(* *)$ & $0.357(* *)$ & 68 & $0.176\left(^{*}\right)$ & $0.412(* *)$ \\
\hline 9 & $0.593(* *)$ & $0.472(* *)$ & 39 & $0.650(* *)$ & $0.524(* *)$ & 69 & $0.349(* *)$ & $0.510(* *)$ \\
\hline 10 & $0.626(* *)$ & $0.571(* *)$ & 40 & $0.484(* *)$ & $0.481(* *)$ & 70 & $0.419(* *)$ & $0.516(* *)$ \\
\hline 11 & $0.601(* *)$ & $0.521(* *)$ & 41 & $0.479(* *)$ & $0.418(* *)$ & 71 & $0.560(* *)$ & $0.497(* *)$ \\
\hline 12 & $0.503(* *)$ & $0.421(* *)$ & 42 & $0.780(* *)$ & $0.368(* *)$ & 72 & $0.611(* *)$ & $0.322(* *)$ \\
\hline 13 & $0.557(* *)$ & $0.383(* *)$ & 43 & $0.738(* *)$ & $0.299(* *)$ & 73 & $0.611(* *)$ & $0.450(* *)$ \\
\hline 14 & $0.547(* *)$ & $0.352(* *)$ & 44 & $0.783(* *)$ & $0.477(* *)$ & 74 & $0.585(* *)$ & $0.616(* *)$ \\
\hline 15 & $0.693(* *)$ & $0.516(* *)$ & 45 & $0.610(* *)$ & $0.368(* *)$ & 75 & $0.520(* *)$ & $0.383(* *)$ \\
\hline 16 & $0.647(* *)$ & $0.471(* *)$ & 46 & $0.750(* *)$ & $0.533(* *)$ & 76 & $0.544(* *)$ & $0.386(* *)$ \\
\hline 17 & $0.618(* *)$ & $0.512(* *)$ & 47 & $0.481(* *)$ & $0.439(* *)$ & 77 & $0.393(* *)$ & $0.417(* *)$ \\
\hline 18 & $0.581(* *)$ & $0.554(* *)$ & 48 & $0.706(* *)$ & $0.266(* *)$ & 78 & $0.647(* *)$ & $0.550(* *)$ \\
\hline 19 & $0.679(* *)$ & $0.578(* *)$ & 49 & $0.689(* *)$ & $0.305(* *)$ & 79 & $0.530(* *)$ & $0.457(* *)$ \\
\hline 20 & $0.485(* *)$ & $0.409(* *)$ & 50 & $0.703(* *)$ & $0.431(* *)$ & 80 & $0.639(* *)$ & $0.524(* *)$ \\
\hline 21 & $0.464(* *)$ & $0.348(* *)$ & 51 & $0.234(* *)$ & $0.238(* *)$ & 81 & $0.606(* *)$ & $0.447(* *)$ \\
\hline 22 & $0.406(* *)$ & $0.302(* *)$ & 52 & $0.427(* *)$ & $0.228(* *)$ & 82 & $0.643(* *)$ & $0.457(* *)$ \\
\hline 23 & $0.592(* *)$ & $0.551(* *)$ & 53 & $0.497(* *)$ & $0.239(* *)$ & 83 & $0.641(* *)$ & $0.538(* *)$ \\
\hline 24 & $0.515(* *)$ & $0.377(* *)$ & 54 & $0.621(* *)$ & $0.451(* *)$ & 84 & $0.616(* *)$ & $0.500(* *)$ \\
\hline 25 & $0.460(* *)$ & $0.386(* *)$ & 55 & $0.606(* *)$ & $0.606(* *)$ & 85 & $0.474(* *)$ & $0.184(*)$ \\
\hline 26 & $0.641(* *)$ & $0.540(* *)$ & 56 & $0.389(* *)$ & $0.364(* *)$ & 86 & $0.366(* *)$ & $0.275(* *)$ \\
\hline 27 & $0.506(* *)$ & $0.411(* *)$ & 57 & $0.694(* *)$ & $0.524(* *)$ & 87 & $0.524(* *)$ & $0.376(* *)$ \\
\hline 28 & $0.659(* *)$ & $0.475(* *)$ & 58 & $0.622(* *)$ & $0.434(* *)$ & 88 & $0.673(* *)$ & $0.528(* *)$ \\
\hline 29 & $0.565(* *)$ & $0.439(* *)$ & 59 & $0.522(* *)$ & $0.319\left(^{* *}\right)$ & 89 & $0.635(* *)$ & $0.362(* *)$ \\
\hline 30 & $0.639(* *)$ & $0.587(* *)$ & 60 & $0.642(* *)$ & $0.546(* *)$ & 90 & $0.551(* *)$ & $0.426(* *)$ \\
\hline
\end{tabular}

$* *$ Correlation is significant at 0.01 . ${ }^{*}$ Correlation is significant at 0.05 
Table 3. It shows the reliability coefficients for the multiple intelligences fields scale

\begin{tabular}{|l|l|l|l|}
\hline Intelligence Field & Reliability coefficient & Split- Half coefficient & $\begin{array}{l}\text { Internal } \\
\text { Consistency } \\
\text { coefficient }\end{array}$ \\
\hline Linguistic Intelligence & 0.82 & 0.75 & 0.76 \\
\hline Logical Mathematical Intelligence & 0.84 & 0.76 & 0.81 \\
\hline Visual Spatial Intelligence & 0.83 & 0.78 & 0.75 \\
\hline Body-Kinesthetic Intelligence & 0.82 & 0.74 & 0.77 \\
\hline Musical Intelligence & 0.81 & 0.88 & 0.88 \\
\hline Interpersonal Intelligence & 0.76 & 0.61 & 0.70 \\
\hline Intrapersonal Intelligence & 0.84 & 0.77 & 0.80 \\
\hline Naturalist Intelligence & 0.79 & 0.75 & 0.78 \\
\hline Existential Intelligence & 0.80 & 0.76 & 0.77 \\
\hline Total & 0.84 & 0.92 & 0.95 \\
\hline
\end{tabular}

Table 4. It shows means, standard deviations, and levels of excellent student's grades on multiple intelligences fields scale, in descending order

\begin{tabular}{|l|l|l|l|}
\hline Fields & $\mathrm{M}$ & $\mathrm{SD}$ & Level \\
\hline Logical Mathematical Intelligence & 4.2760 & 0.58380 & High \\
\hline Interpersonal Intelligence & 4.2580 & 0.74256 & High \\
\hline Body-Kinesthetic Intelligence & 4.2280 & 0.76152 & High \\
\hline Visual Spatial Intelligence & 4.2025 & 0.63881 & High \\
\hline Existential Intelligence & 4.1545 & 0.70210 & High \\
\hline Naturalist Intelligence & 4.1385 & 0.61934 & High \\
\hline Intrapersonal Intelligence & 4.1380 & 0.65888 & High \\
\hline Linguistic Intelligence & 3.9035 & 0.50159 & High \\
\hline Musical Intelligence & 3.7675 & 0.67093 & High \\
\hline
\end{tabular}

Table 5. It shows means, standard deviations, and levels of normal student's grades on multiple intelligences fields scale, in descending order

\begin{tabular}{|l|l|l|l|}
\hline Fields & $\mathrm{M}$ & SD & Level \\
\hline Musical Intelligence & 2.6465 & 0.90375 & Average \\
\hline Linguistic Intelligence & 2.6060 & 0.81176 & Average \\
\hline Visual Spatial Intelligence & 2.4915 & 0.81361 & Average \\
\hline Naturalist Intelligence & 2.4865 & 0.60704 & Average \\
\hline Logical Mathematical Intelligence & 2.4805 & 0.93709 & Average \\
\hline Body-Kinesthetic Intelligence & 2.3930 & 0.99239 & Average \\
\hline Intrapersonal Intelligence & 2.3775 & 0.89390 & Average \\
\hline Existential Intelligence & 2.3380 & 0.72971 & Average \\
\hline Interpersonal Intelligence & 2.2945 & 0.88704 & Average \\
\hline
\end{tabular}


Table 6. It shows means, standard deviations, and T-Value of excellent and normal student's grades on multiple intelligences fields scale

\begin{tabular}{|c|c|c|c|c|c|c|c|}
\hline Fields & $\begin{array}{l}\text { Academic } \\
\text { classification }\end{array}$ & M & $\mathrm{SD}$ & $t$ & $\mathrm{DF}$ & Sig & $\begin{array}{l}\text { Amount of } \\
\text { Difference }\end{array}$ \\
\hline \multirow[t]{2}{*}{ Linguistic Intelligence } & Excellent students & 3.9035 & 0.5015 & \multirow{2}{*}{19.230} & \multirow{2}{*}{398} & \multirow{2}{*}{$0.000 *$} & \multirow{2}{*}{1.2975} \\
\hline & Normal students & 2.6060 & 0.8117 & & & & \\
\hline \multirow{2}{*}{ Logical Mathematical Intelligence } & Excellent students & 4.2760 & 0.5838 & \multirow{2}{*}{21.336} & \multirow{2}{*}{398} & \multirow{2}{*}{$0.000 *$} & \multirow{2}{*}{1.7955} \\
\hline & Normal students & 2.4805 & 1.037 & & & & \\
\hline \multirow[t]{2}{*}{ Visual Spatial Intelligence } & Excellent students & 4.2025 & 0.6388 & \multirow{2}{*}{20.196} & \multirow{2}{*}{398} & \multirow{2}{*}{$0.000^{*}$} & \multirow{2}{*}{1.7110} \\
\hline & Normal students & 2.4915 & 1.013 & & & & \\
\hline \multirow[t]{2}{*}{ Body-Kinesthetic Intelligence } & Excellent students & 4.2280 & 0.7612 & \multirow{2}{*}{19.488} & \multirow{2}{*}{398} & \multirow{2}{*}{$0.000 *$} & \multirow{2}{*}{1.8350} \\
\hline & Normal students & 2.3930 & 1.092 & & & & \\
\hline \multirow[t]{2}{*}{ Musical Intelligence } & Excellent students & 3.7675 & 0.6709 & \multirow{2}{*}{14.085} & \multirow{2}{*}{398} & \multirow{2}{*}{$0.000 *$} & \multirow{2}{*}{1.1210} \\
\hline & Normal students & 2.6465 & 0.9037 & & & & \\
\hline \multirow[t]{2}{*}{ Interpersonal Intelligence } & Excellent students & 4.2580 & 0.7425 & \multirow{2}{*}{19.832} & \multirow{2}{*}{398} & \multirow{2}{*}{$0.000 *$} & \multirow{2}{*}{1.9635} \\
\hline & Normal students & 2.2945 & 1.187 & & & & \\
\hline \multirow[t]{2}{*}{ Intrapersonal Intelligence } & Excellent students & 4.1380 & 0.6588 & \multirow{2}{*}{19.497} & \multirow{2}{*}{398} & \multirow{2}{*}{$0.000 *$} & \multirow{2}{*}{1.7605} \\
\hline & Normal students & 2.3775 & 1.093 & & & & \\
\hline \multirow[t]{2}{*}{ Naturalist Intelligence } & Excellent students & 4.1385 & 0.6193 & & & & \\
\hline & Normal students & 2.4865 & 1.007 & 19.101 & 390 & 0.000 & 1.0520 \\
\hline Existential Intelligence & Excellent students & 4.1545 & 0.7021 & & & & \\
\hline & Normal students & 2.3380 & 1.129 & & & & \\
\hline
\end{tabular}


Table 7. It shows means, standard deviations, and T-Value of excellent student's grades on multiple intelligences fields scale

\begin{tabular}{|c|c|c|c|c|c|c|c|c|}
\hline $\begin{array}{l}\text { Academic } \\
\text { classification }\end{array}$ & Fields & Gender & $\mathrm{M}$ & SD & $\mathrm{t}$ & DF & Sig & $\begin{array}{l}\text { Amount of } \\
\text { Difference }\end{array}$ \\
\hline \multirow{18}{*}{$\begin{array}{l}\text { Excellent } \\
\text { students }\end{array}$} & \multirow[t]{2}{*}{ Linguistic Intelligence } & Male & 3.9371 & 0.37857 & \multirow{2}{*}{.997} & \multirow{2}{*}{198} & \multirow{2}{*}{0.320} & \multirow{2}{*}{0.0708} \\
\hline & & Female & 3.8663 & 0.60943 & & & & \\
\hline & \multirow[t]{2}{*}{ Logical Mathematical Intelligence } & Male & 4.4038 & 0.35786 & \multirow{2}{*}{198} & \multirow{2}{*}{198} & \multirow{2}{*}{0.269} & \multirow{2}{*}{0.198} \\
\hline & & Female & 4.1347 & 0.73583 & & & & \\
\hline & \multirow[t]{2}{*}{ Visual Spatial Intelligence } & Male & 4.2571 & 0.47106 & \multirow{2}{*}{1.274} & \multirow{2}{*}{198} & \multirow{2}{*}{0.204} & \multirow{2}{*}{0.1150} \\
\hline & & Female & 4.1421 & 0.78192 & & & & \\
\hline & \multirow[t]{2}{*}{ Body-Kinesthetic Intelligence } & Male & 4.2686 & 0.65945 & \multirow{2}{*}{.791} & \multirow{2}{*}{198} & \multirow{2}{*}{0.430} & \multirow{2}{*}{0.0854} \\
\hline & & Female & 4.1832 & 0.86180 & & & & \\
\hline & \multirow[t]{2}{*}{ Musical Intelligence } & Male & 3.7571 & 0.58092 & \multirow{2}{*}{-.229} & \multirow{2}{*}{198} & \multirow{2}{*}{0.819} & \multirow{2}{*}{-0.0218} \\
\hline & & Female & 3.7789 & 0.76114 & & & & \\
\hline & \multirow[t]{2}{*}{ Interpersonal Intelligence } & Male & 4.3552 & 0.49788 & \multirow{2}{*}{1.961} & \multirow{2}{*}{198} & \multirow{2}{*}{0.051} & \multirow{2}{*}{0.2047} \\
\hline & & Female & 4.1505 & 0.93318 & & & & \\
\hline & \multirow[t]{2}{*}{ Intrapersonal Intelligence } & Male & 4.1743 & 0.46472 & \multirow{2}{*}{.818} & \multirow{2}{*}{198} & \multirow{2}{*}{0.414} & 0.0764 \\
\hline & & Female & 4.0979 & 0.82281 & & & & \\
\hline & Naturalist Intelligence & Male & 4.2295 & 0.44547 & 2206 & 198 & $0029 *$ & 01916 \\
\hline & & Female & 4.0379 & 0.75698 & 2.200 & 190 & 0.029 & 0.1910 \\
\hline & Existential Intelligence & Male & 4.2171 & 0.54622 & 320 & 108 & 0185 & 01310 \\
\hline & & Female & 4.0853 & 0.83920 & 1.529 & 190 & 0.105 & 0.1519 \\
\hline
\end{tabular}

Table 8. It shows means, standard deviations, and T-Value of normal student's grades on multiple intelligences fields scale

\begin{tabular}{|c|c|c|c|c|c|c|c|c|}
\hline $\begin{array}{l}\text { Academic } \\
\text { classification }\end{array}$ & Fields & Gender & M & SD & $\mathrm{t}$ & DF & Sig & $\begin{array}{l}\text { Amount of } \\
\text { Difference }\end{array}$ \\
\hline \multirow{18}{*}{ Normal students } & \multirow[t]{2}{*}{ Linguistic Intelligence } & Male & 2.6734 & 0.77698 & \multirow{2}{*}{1.106} & \multirow{2}{*}{198} & \multirow{2}{*}{0.270} & \multirow{2}{*}{0.1272} \\
\hline & & Female & 2.5462 & 0.84054 & & & & \\
\hline & \multirow{2}{*}{$\begin{array}{l}\text { Logical Mathematical } \\
\text { Intelligence }\end{array}$} & Male & 2.6106 & 1.03938 & \multirow{2}{*}{1.679} & \multirow{2}{*}{198} & \multirow{2}{*}{0.095} & \multirow{2}{*}{0.2455} \\
\hline & & Female & 2.3651 & 1.02614 & & & & \\
\hline & \multirow[t]{2}{*}{ Visual Spatial Intelligence } & Male & 2.5904 & 1.03841 & \multirow{2}{*}{1.302} & \multirow{2}{*}{198} & \multirow{2}{*}{0.194} & \multirow{2}{*}{0.1867} \\
\hline & & Female & 2.4038 & .98773 & & & & \\
\hline & \multirow[t]{2}{*}{ Body-Kinesthetic Intelligence } & Male & 2.5074 & 1.06723 & \multirow{2}{*}{1.399} & \multirow{2}{*}{198} & \multirow{2}{*}{0.163} & \multirow{2}{*}{0.2159} \\
\hline & & Female & 2.2915 & 1.10936 & & & & \\
\hline & \multirow[t]{2}{*}{ Musical Intelligence } & Male & 2.6979 & .82761 & \multirow{2}{*}{.756} & \multirow{2}{*}{198} & \multirow{2}{*}{0.450} & \multirow{2}{*}{0.0969} \\
\hline & & Female & 2.6009 & .96791 & & & & \\
\hline & \multirow[t]{2}{*}{ Interpersonal Intelligence } & Male & 2.4809 & 1.19058 & \multirow{2}{*}{2.109} & \multirow{2}{*}{198} & \multirow{2}{*}{$0.036^{*}$} & \multirow{2}{*}{0.3516} \\
\hline & & Female & 2.1292 & 1.16463 & & & & \\
\hline & \multirow[t]{2}{*}{ Intrapersonal Intelligence } & Male & 2.5021 & 1.05810 & \multirow{2}{*}{1.522} & \multirow{2}{*}{198} & \multirow{2}{*}{0.130} & 0225 \\
\hline & & Female & 2.2670 & 1.11805 & & & & 0.2351 \\
\hline & Naturalist Intelligence & Male & 2.5830 & .99522 & 70 & 100 & 0202 & 0107 \\
\hline & & Female & 2.4009 & 1.01442 & 1.278 & 198 & 0.203 & $0.18<0$ \\
\hline & Existential Intelligence & Male & 2.4819 & 1.12966 & - & 100 & 0 & 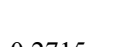 \\
\hline & & Female & 2.2104 & 1.11960 & 1.705 & 198 & 0.090 & 0.2715 \\
\hline
\end{tabular}

